\title{
Razvoj in novi teoretični in metodološki koncepti ter aplikacija socialne geografije
}

\author{
Primer hitrega krčenja kmetijskega prostora z manjšanjem \\ obsega izkoriščanja kmetijske zemlje, ogroženost podobe \\ kulturne pokrajine in rušenje ekološkega ravnotežja \\ v Sloveniji
}

\author{
Vladimir Klemenčič \\ Dr., Oddelek za geografijo, Filozofska fakulteta, Univerza v Ljubljani, \\ Aškerčeva 2, 1000 Ljubljana, Slovanija \\ e-mail: matjaz.klemencic@siol.net
}

\section{Izvleček}

$\checkmark$ prispevku so predstavljene nova metodologija, teorija in aplikacija socialne geografije v praksi, ki so se razvile pod vplivom evropske integracije Slovenije in oblikovanja tržnega kmetijstva Evropske unije. Posledice prilagajanja slovenskega kmetijstva zahtevam Evropske unije se že kažejo v novih potezah podobe kmetijskega prostora, posledično pa tudi v celotni podobi in funkciji kulturne pokrajine.

Ključne besede: socialna geografija, tržno kmetijstvo, oblikovanje agrarnega prostora, kmetijska zemljišča v zaraščanju

\section{Development and new theoretical and methodological concepts and application of social geography}

\begin{abstract}
In this paper new methodology, theory and application of social geography as develop in praxis under the influence of Slovenia's accession to the EU and development of farming for the market in EU. The consequences of the process of adaptation of Slovenian farming to the demands of EU already seen in new ways of farming in Slovenia as well as in changing function of cultural landscape.
\end{abstract}

Key words: social geography, market farming, creation of the agrarian space, abandoned agricultural land 


\section{TEORETIČNA IN METODOLOŠKA IZHODIŠČA}

Za razvoj socialne in z njo povezane politične geografije je značilno, da si s svojim dinamičnim konceptom zastavljata naloge permanentnega dopolnjevanja teorije, metodologije in aplikacije z novimi spoznanji. Pri tem posvečata posebno pozornost novim izzivom prostora moderne demokratične družbe na lokalni, državni, evropski in globalni ravni. Tak koncept jima omogoča opredeliti probleme sodobnih prostorskih procesov v medsebojni povezanosti vseh dejavnikov, ki vplivajo na preoblikovanje prostora. Ob tem pa ta koncept $\mathrm{v}$ okviru interdisciplinarnega proučevanja in z ustreznimi pristopi načrtovanja prostorskega razvoja prispeva k smotrnemu oblikovanju kulturne pokrajine, vendar le pod pogojem, da to načrtovanje ustreza potrebam vseh dejavnikov razvoja prostora (kmetijstva, industrije, drobnega gospodarstva, prometa, storitvenih dejavnosti in javnih služb). To pomeni, da morajo biti načrtovalci in uporabniki prostora $\mathrm{v}$ tesni medsebojni povezanosti, in to tako pri načrtovanju prostorskega razvoja kot pri izvajanju načrta oblikovanja kulturne pokrajine.

$\mathrm{Ob}$ takem konceptu socialne geografije smo priča oblikovanju nove filozofije postopkov prenosa metodologije in teorije v prakso. Socialna geografija si je s takim pristopom zagotovila svoje mesto $\mathrm{v}$ novem interdisciplinarno zasnovanem proučevanju in načrtovanju prostora na vseh ravneh, od lokalne in nacionalne do globalne. Ker njeni prispevki temeljijo na izhodiščih prepletenosti učinkov družbenega in gospodarskega razvoja $\mathrm{z}$ varovanjem okolja, so ti že prisotni tudi v konceptih ter navodilih Evropske unije za urejanje podeželja (Hilpert, 2002; Schaffer, 2002; Zettler, 2001).

\section{POLITIKA IZRABE KMETIJSKEGA PROSTORA V SLOVENIJI}

$\mathrm{V}$ sodobnih prostorskih procesih predstavljata kmetijska in regionalna politika enega najpomembnejših dejavnikov v načrtovanju smotrnega oblikovanja agrarnega prostora kulturne pokrajine. Kako pomemben je ta dejavnost za oblikovanje kulturne pokrajine, vidimo na primeru Slovenije, kjer kmetijstvo izkorišča in $\mathrm{s}$ tem prispeva $\mathrm{k}$ oblikovanju več kot tretjine vsega prostora. Pri tem ne smemo pozabiti, da bo slovensko kmetijstvo preko politike doplačil in kvot za subvencionirano proizvodnjo kmalu odvisno od kmetijske politike Evropske unije. Tako bo Evropska unija posredno določala tudi obseg prostora namenjenega za subvencionirano kmetijstvo in tem zakonitostim se bomo morali ob vstopu v Evropsko unijo podrediti. Pri tem je potrebno opozoriti, da se zaradi "evropske" kmetijske politike obseg obdelanih kmetijskih površin v državah 
Evropske unije nenehno krči in to tako na območjih z omejenimi, kot na območjih z ugodnimi pogoji za tržno kmetijsko proizvodnjo.

V vseh razvitih deželah prihaja do krčenja obdelave kmetijskih zemljišč primernih za kmetijsko proizvodnjo tudi zaradi uvajanja moderne tehnologije v kmetijstvu. Vendar pa se oblike gospodarjenja s temi zemljišči zelo razlikujejo od države do države. Ponekod takšna zemljišča deloma ali v celoti prepuščajo stihijskemu zaraščanju, ponekod pa take površine $\mathrm{z}$ različnimi oblikami finančne pomoči vzdržujejo še naprej, da bi jih po potrebi lahko znova vključili v kmetijsko izrabo. Med države, ki opuščena kmetijska zemljišča v glavnem prepušča stihijskemu zaraščanju, sodi tudi Slovenija, saj temu pojavu ne posveča skoraj nobene pozornosti niti v kmetijski politiki niti v načrtovanju regionalno-prostorskega razvoja.

Na probleme, ki sta jih odpirala urbanizacija podeželja in oblikovanje nerazvitih območij, opozarjamo geografi z evropsko primerljivimi rezultati socialno-geografskih proučevanj že od sedemdesetih let 20. stoletja naprej (Študije o kmetijski izrabi tal v treh vaseh Jugoslavije, 1962: 61-114). Rezultati, ki so temeljili na zamudnih in dragih postopkih (anketiranje in kartiranje izbranih območij Slovenije), pa zaradi pomanjkanja interdisciplinarne miselnosti pri načrtovalcih prostorskega razvoja in odgovornih za kmetijstvo niso imeli pravega odmeva. Izsledki, teorija, metodologija in aplikacija socialno-geografskih raziskav nimajo prave veljave niti danes, saj jih slovenska politika ter odgovorni za prostorski in regionalni razvoj le redko upoštevajo v praksi.

Ob problemih, ki danes bremenijo slovensko kmetijstvo, se moramo zavedati, da je le-to $\mathrm{v}$ relativno kratkem času prešlo - glede na pogoje izrabe kmetijske zemlje - skozi več razvojnih faz. Tako sta bili vse do začetka šestdesetih let 20. stoletja glavni značilnosti slovenskega podeželje agrarna prenaseljenost in izkoriščenost skoraj vseh razpoložljivih kmetijskih površin, ki so bile ne glede na naravne danosti vezane $\mathrm{v}$ glavnem le na ročno delo. $V$ šestdesetih letih je slovensko kmetijstvo začelo $\mathrm{z}$ uvajanjem kmetijske tehnologije prehajati v fazo optimalne izkoriščenosti kmetijskih površin. To fazo sta zaznamovala zlasti uveljavljanje strojne obdelave in razvoj polkmečke strukture prebivalstva na gospodarsko razvitih območjih ter opuščanje za kmetijstvo manj primernih zemljišč na manj razvitih območjih, kjer je že zelo zgodaj začelo prihajati tudi do razpada kulturne pokrajine. Ta faza je trajala vse do začetka devetdesetih let 20. stoletja oziroma do osamosvojitve Slovenije, ki je povezana $\mathrm{z}$ gospodarsko in politično tranzicijo. Po osamosvojitvi se je v slovenskem kmetijstvu začel hiter proces opuščanja obdelanih kmetijskih površin, kar je vidno tudi v zunanjem izgledu pokrajine. Kako hiter je bil ta proces nam kažejo - sicer ne ravno zanesljivi - podatki zemljiškega katastra in podatki o kmetijskih zemljiščih v uporabi (KZU) Statističnega urada Republike Slovenije (SURS). 
Tabela 1: Kmetijska zemlja po podatkih katastra in SURS - v hektarjih

\begin{tabular}{|c|c|c|c|}
\hline leto & kmetijska zemlja po katastru & KZU po podatkih SURS & razlika \\
\hline 1990 & 905.500 & 866.405 & 39.095 \\
\hline 1991 & 899.500 & 865.848 & 33.652 \\
\hline 1994 & 899.100 & 548.969 & 350.131 \\
\hline 1996 & 887.200 & 524.454 & 362.746 \\
\hline 1997 & 885.600 & 494.035 & 391.565 \\
\hline 1998 & 883.700 & 490.863 & 392.837 \\
\hline
\end{tabular}

Vira: Podatkovna baza zemljiškega katastra; SURS

Če primerjamo podatke omenjenih virov, lahko v obdobju 1990-1998 ugotavljamo vse večjo razliko, ki bi teoretično lahko predstavljala neizrabljena kmetijska zemljišča - leta 1998 naj bi obsegala okrog 45\% vse kmetijske zemlje, leta 1990 pa le okrog 3 \%. (Pregled kmetijske politike Slovenije, 2001: 41). Vzroki za neizrabljena kmetijska zemljišča v Sloveniji so zelo različni. Po dosedanjih izkušnjah je eden glavnih neustrezna zemljiška struktura, saj je leta 1991 povprečna slovenska kmetija imela le 5,9 ha zemlje. Od tega je bilo kmetijskih zemljišč 3,2 ha, obdelovalnih zemljišč pa le 2,5 ha.

Tabela 2: Število družinskih kmetij glede na velikost uporabljenih kmetij. površin.

\begin{tabular}{|l|r|r|r|r|r|r|}
\hline & \multicolumn{2}{|c|}{ leto 1991 } & \multicolumn{2}{|c|}{ leto 1997 } & \multicolumn{2}{|c|}{ leto 2000 } \\
\cline { 2 - 7 } & število & \% & število & \% & število & $\%$ \\
\hline $\begin{array}{l}\text { družinske } \\
\text { kmetije skupaj }\end{array}$ & 111.961 & 100,0 & 90.613 & 100,0 & 86.336 & 100,0 \\
\hline brez KZU & 20 & 0,0 & 34 & 0,0 & 16 & 0,0 \\
\hline 1,00 ha in manj & 15.576 & 13,9 & 8.111 & 9,0 & 7.998 & 9,3 \\
\hline $1,01-3,00$ ha & 41.062 & 36,7 & 30.940 & 34,1 & 27.251 & 31,6 \\
\hline $3,01-5,00$ ha & 22.868 & 20,4 & 20.070 & 22,2 & 18.128 & 21,0 \\
\hline $5,01-10,00$ ha & 24.251 & 21,7 & 22.762 & 25,1 & 22.053 & 25,5 \\
\hline $10,01-20,00$ ha & 7.251 & 6,5 & 7.759 & 8,6 & 9.158 & 10,6 \\
\hline 20,01 ha in več & 923 & 0,8 & 937 & 1,0 & 1.732 & 2,0 \\
\hline
\end{tabular}

VIR: Statistični letopis RS 40 (2001), Ljubljana, Statistični urad Republike Slovenije.

Ta neugodna zemljiška struktura se je nekoliko izboljšala šele v zadnjem desetletju, $v$ glavnem na račun dokupa in najemanja zemlje. Tako v zemljiškoposestni strukturi sedaj prevladujejo kmetije s 5-10 ha zemlje, narašča pa tudi število kmetij, ki obdelujejo več kot 10 ha zemlje (Cunder, 2000: 22-25). 
Slika 1: Spremembe v številu kmetij in kmetijski zemlji v uporabi po velikostnih razredih kmetij, 1991 - 1997

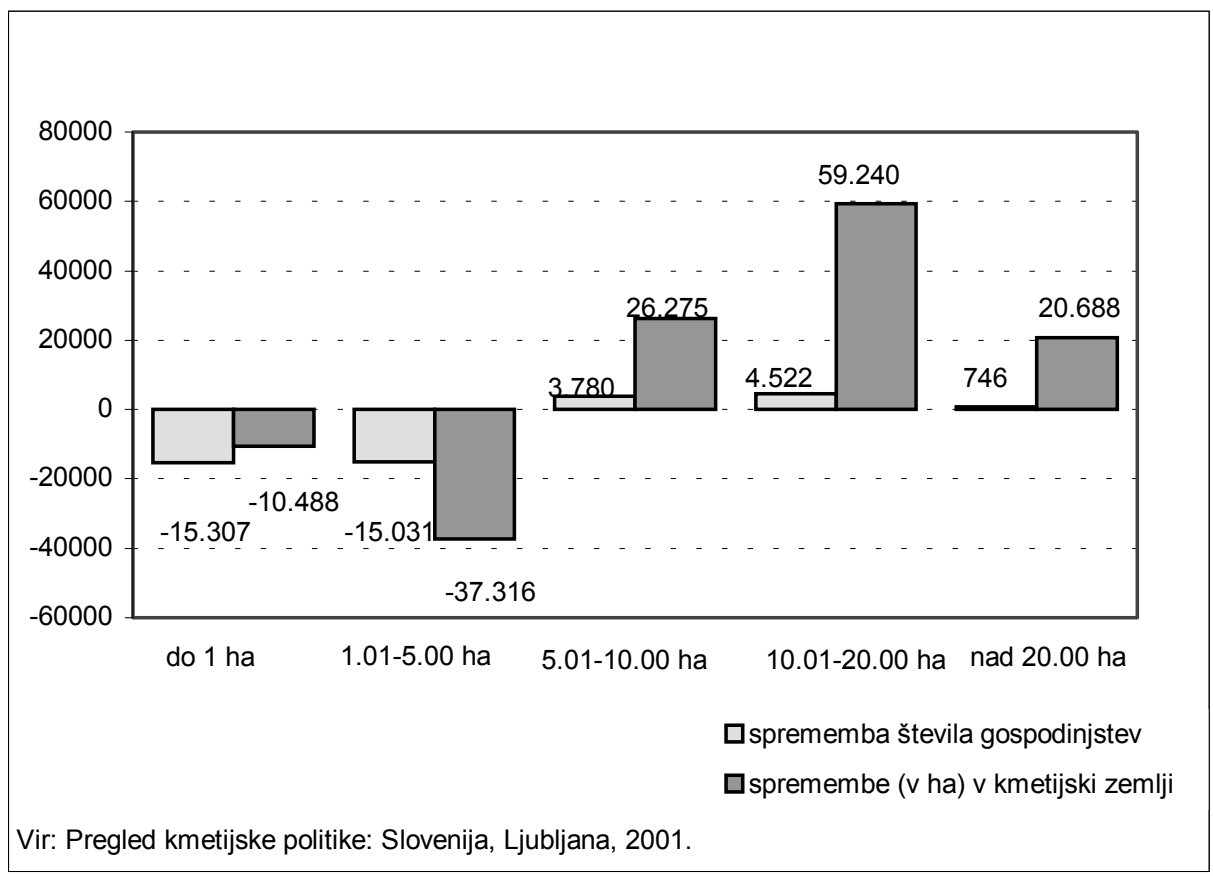

Zemljiška struktura se je $\mathrm{v}$ zadnjem desetletju izboljšala tudi na račun upadanja števila družinskih kmetij. Le-to je samo med letoma 1991 in 1997 upadlo od 111.691 na 86.363. Po ocenah Ministra za kmetijstvo, gozdarstvo in prehrano Republike Slovenije dr. Franca Buta pa naj bi bilo leta 2002 tržno usmerjenih le okrog 65.000 družinskih kmetij.

$\mathrm{Na}$ opuščanje obdelave zemlje vpliva tudi tradicionalna in zastarela zemljiška razdelitev (na "pravilne" in "nepravilne delce" ter na "grude" in "proge") ter razdrobljenost kmetijske zemlje. Po podatkih popisa iz leta 1991 je bilo v Sloveniji dobrih 5,5 milijona parcel, katerih povprečna velikost je $\mathrm{v}$ zasebnem sektorju znaša okrog 29,9 arov. Te parcele so bile združene v okrog 955.000 ločenih zemljiških kosov. Posamezne družinske kmetije imajo tako kmetijsko zemljo razdeljeno tudi v več kot 20 kosov, ki so ponekod tudi več kot $10 \mathrm{~km}$ oddaljeni od kmetije. To seveda povečuje izdatke kmetijske proizvodnje (zaradi izgube časa in višjih izdatkov transporta) in zmanjšuje možnost racionalne uporabe sodobne kmetijske tehnologije. 
Tabela 3: Družinske kmetije in bilanca zemljišč družinskih kmetij, 1991-2002.

\begin{tabular}{|l|r|r|r|r|}
\hline & Popis 1991 & SPK 1997 & PKG 2000 & $\begin{array}{r}\text { tržno usmerjene } \\
\text { kmetije - 2002* }\end{array}$ \\
\hline $\begin{array}{l}\text { število gospodinjstev } \\
\text { kmečkim gospodarstvom }\end{array}$ & 156.549 & n.p. & n.p. & ca. 120.000 \\
\hline število družinskih kmetij & 111.961 & 90.613 & 86.336 & cca. 65.000 \\
\hline vsa zemljišča (v ha) & n.p. & n.p. & 918.904 & n.p. \\
\hline vsa kmetijska zemljišča & n.p. & n.p. & 507.404 & n.p. \\
\hline KZU (v ha) & 491.541 & 433.142 & 456.214 & $(450.000)^{* *}$ \\
\hline ha KZU/kmetijo & 4,39 & 4,78 & 5,28 & cca. 7 ha \\
\hline
\end{tabular}

OPOMBE: SPK - strukturni popis kmetijstva; PKG - popis kmetijskih gospodarstev; n.p. - ni ustreznega podatka; * Ocena Ministra za kmetijstvo, gozdarstvo in prehrano Republike Slovenije dr. Franca Buta; ** samo KZU tržno usmerjenih kmetij

VIRI: Strukturni popis kmetijstva 1997, Ljubljana: Statistični urad Republike Slovenije, 1997; Popis kmetijskih gospodarstev, Slovenija, 2000. Rezultati raziskovanj št. 777, Ljubljana, Statistični urad Republike Slovenije, 2002; Viktor Luskovec, "Izganjalec kmečkega socializma”. Nedelo, leto 8, št. 35, Ljubljana, 1. septembra 2002, str. 5.

Slika 2: Družinske kmetije po številu kosov kmetij. zemlje v uporabi (leta 2000)

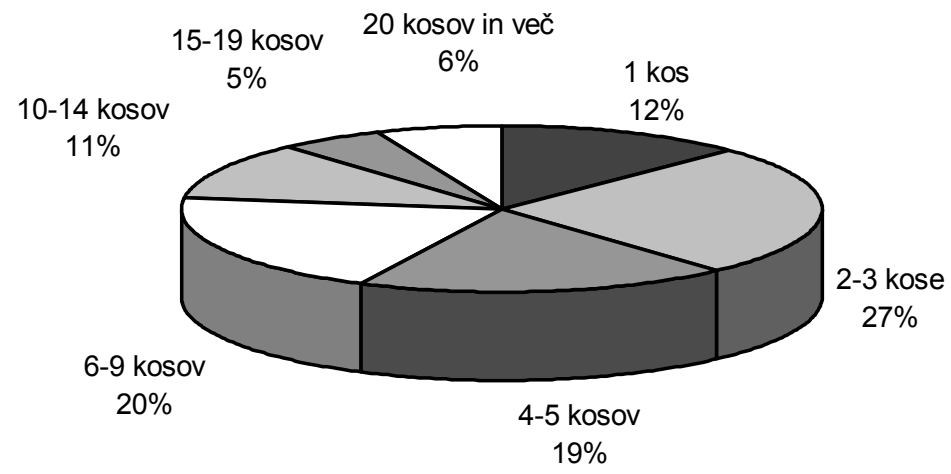

Vir: Popis kmetijskih gospodarstev, 2000.

Ker majhne kmetije $\mathrm{z}$ razdrobljeno zemljiško strukturo družinam $\mathrm{v}$ glavnem niso nudile zadostnih osnov za preživetje, so si mnogi lastniki od šestdesetih let 20. stoletja dalje iskali dodatnega zaslužka $\mathrm{v}$ nekmečkih poklicih. To je sčasoma privedlo do oblikovanja mešane delavsko-kmečke strukture gospo- 
dinjstev in tako je bila leta 1991 odvisna izključno od dohodkov iz kmetijstva (tako imenovane čiste kmetije) le še dobra petina družinskih kmetij. Do leta 1997 je število čistih družinskih kmetij upadlo na šestino, glede na trende pa kaže, da bo njihovo upadalo tudi po vključitvi v Evropsko unijo

Tabela 4: Število družinskih kmetij po socio-ekonomskih tipih.

\begin{tabular}{|l|r|r|r|r|}
\hline \multirow{2}{*}{} & \multicolumn{2}{|c|}{ leto 1991 } & \multicolumn{2}{|c|}{ leto 1997 } \\
\cline { 2 - 5 } & število & \% & število & \% \\
\hline družinske kmetije - skupaj & 111.546 & 100,0 & 90.613 & 100,0 \\
\hline čiste kmetije & 23.765 & 21,3 & 13.849 & 15,3 \\
\hline mešane kmetije & 55.585 & 49,8 & 25.287 & 27,9 \\
\hline dopolnilne kmetije & 21.412 & 19,2 & 41.782 & 46,1 \\
\hline ostarele kmetije & 10.784 & 9,7 & 9.695 & 10,7 \\
\hline
\end{tabular}

VIR: Strukturni popis kmetijstva (SPK) 1997, Ljubljana, Statistični urad republike Slovenije.

Učinki prehajanja lastnikov manjših kmetij v nekmečke poklice so se kazali zlasti v vse manjši izkoriščenosti kmetijske zemlje (Kürbus, 1992). Sprva se je proces opuščanja obdelave $\mathrm{v}$ večjem obsegu uveljavil le na manj primernih območjih za kmetijstvo, oziroma na območjih, ki jih danes opredeljujemo kot manj razvita območja, v obdobju po osamosvojitvi pa se je razširil bolj ali manj na vse slovensko podeželje. Vzroke za to moremo iskati tudi v neugodni starostni sestavi gospodinjstev na družinskih kmetijah, ki je posledica odseljevanja mladega prebivalstva iz podeželja $v$ času industrializacije Slovenije. Tako zastopajo danes osebe starejše od 55 let že skoraj tretjino skupnega števila članov na družinskih kmetijah.

Še slabša pa je starostna struktura delovne sile na družinskih kmetijah (osebe starejše od 15 let, ki so na kmetijskem gospodarstvu opravljale kakšno delo), kjer prevladujejo osebe v pozni aktivni dobi ali zunaj nje, oziroma starejši od 55 let. Te namreč predstavljajo skoraj polovico delovne sile na družinskih kmetijah.

Tudi v starostni sestavi gospodarjev družinskih kmetij prevladujejo starejši gospodarji. Tako gospodarji, ki so starejši od 55 let, prevladujejo na večini kmetij do velikosti 20 ha KZU. Šele na kmetijah, večjih od 20 ha KZU, delež gospodarjev mlajših od 45 let preseže delež gospodarjev starejših od 55 let. 
Slika 3: Delovna sila na družinskih kmetijah po starostnih skupinah (l. 2000)

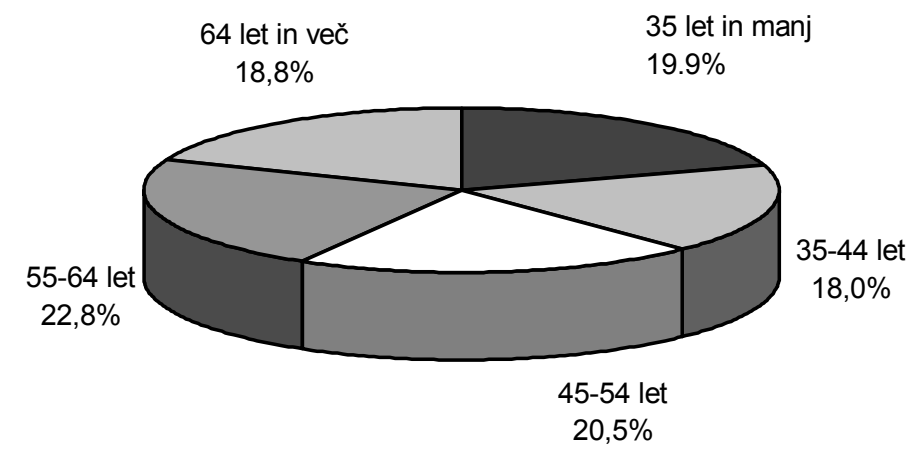

Vir: Popis kmetijskih gospodarstev, 2000.

Slika 4: Gospodarji družinskih kmetij po starostnih skupinah (leta 2000)

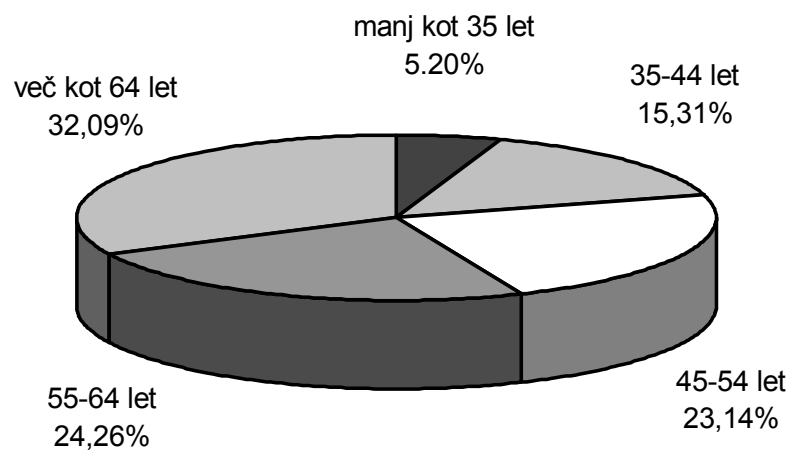

Vir: Popis kmetijskih gospodarstev, 2000.

V povezavi s starostno strukturo je tudi izobrazbena struktura prebivalstva družinskih kmetij. Zlasti pri starejših gospodarjih družinskih kmetij je raven dosežene šolske izobrazbe precej nižja od povprečja drugih skupin aktivnega 
prebivalstva $\mathrm{v}$ Sloveniji $\mathrm{v}$ enaki starostni kategoriji. Tako je brez formalne izobrazbe ali pa ima dokončano le osnovno šolo skoraj 59 \% gospodarjev družinskih kmetij. Nekoliko boljša je splošna izobrazbena ravan naslednikov, kjer v povprečju prevladujejo nasledniki s končano poklicno ali srednješolsko izobrazbo.

Slika 5: Družinske kmetije po šolski izobrazbi gospodarjev in naslednikov (l. 2000)

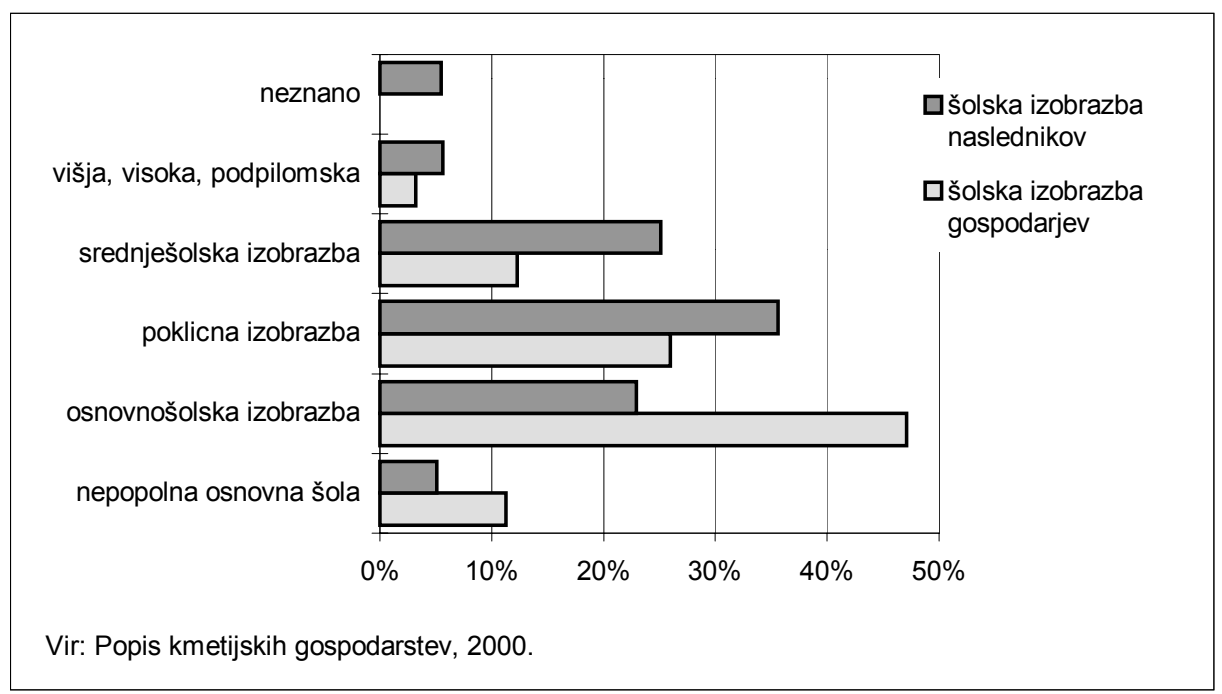

Kljub tendencam izboljševanja splošne izobrazbe, pa perspektiva slovenskega kmetijstva zaradi neugodne starostne strukture ni najbolj obetavna. Številne kmetije so zaradi odseljevanja mladega prebivalstva ostale brez zadostne delovne sile ali pa je ta ostarela. Veliko je tudi neporočenih gospodarjev, tako da kmetije ostajajo brez naslednikov. Vse to pa vpliva in bo tudi v prihodnosti vplivalo na nadaljnje opuščanje izrabe kmetijske zemlje.

Posledice opuščanja obdelave kmetijskih zemljišč so najbolj vidne na ravnem svetu manjših kotlin in dolin ter na bolj ali manj obsežnih slemenih terciarnega gričevja submediteranskega (Šavrini, Brkini), subpanonskega (Goričko, Slovenske gorice, Haloze, Dravinjske gorice) in predalpskega sveta. To je na območjih, ki bi bila primerna za nadaljnjo obdelavo le v primeru združevanja majhnih parcel $\mathrm{v}$ večje komplekse. Na nekaterih kraških poljih in dolinah - zlasti tistih, ki so oddaljene od kmečkih naselij ali kmetij - pa lahko sledimo že tudi popolni opustitvi obdelave zemlje. Opuščene pa so tudi nekdaj izkoriščene travne jase sredi gozdov hribovitega sveta. Pravzaprav lahko danes 
sledimo opuščanju obdelave za kmetijstvo primerne zemlje skoraj po vsej Sloveniji. Ta proces se v prikriti obliki kaže v slabo negovanih travnikih tudi na ravnini (npr. na Bistriški ravnini, na Ljubljanskem barju), ali pa v neobdelanih površinah (na območju med Postojno in Ilirsko Bistrico). Znake opuščanja obdelave kvalitetne zemlje lahko ugotavljamo tudi na obrobju Ljubljane (Savlje, Ljubljansko polje) ter v bližnji okolici drugih centralnih krajev.

\section{SODOBNI PROBLEMI KMETIJSKE IZRABE ZEMLJE V SLOVENIJI}

Učinki divje urbanizacije podeželja in neustrezna štiridesetletna socialistična kmetijska politika v Sloveniji (omejevanje velikosti kmetij na največ 10 ha, dedni zakon, ki je dovoljeval drobljenje kmetij) so slaba popotnica slovenske kmetijske politike pri prilagajanju slovenskega kmetijstva evropskim zahtevam. Ob vprašanju načina gospodarjenja $\mathrm{z}$ opuščenimi kmetijskimi zemljišči bo moralo slovensko kmetijstvo rešiti še probleme neustrezne zemljiške strukture, predvsem pa zmanjšati delež kmetijske zemlje v lasti nekmetov. Le tako bo lahko slovensko zasebno kmetijstvo konkurenčno na evropskem in svetovnem tržišču.

Z vzroki in posledicami opuščanja zemlje se bodo morali ukvarjati zlasti kmetijski in regionalni politiki, načrtovalci prostorskega razvoja ter ekologi, pri čemer pa se skoraj ne bodo mogli izogniti dosedanjim izkušnjam in izsledkom socialne geografije. Vendar pa v Sloveniji posvečamo le malo pozornosti opuščanju obdelave zemlje (Erjavec, 1992; Plut, 2002; Kovačič, 1999: 53-59; Cunder, 2000: 22-25). Še težje pa je razložljivo, da ta problem sploh ni upoštevan pri navodilih za izvedbo programa uvajanja CRP-ov in izdelavo razvojnega projekta CRP-ov, kar se kaže iz publikacije, v kateri so predstavljena navodila in rezultati raziskav (Pelc, ur., 1999).

$\mathrm{Ob}$ modernih pogledih na vzdrževanje kulturne pokrajine in njenega ekološkega varovanja se v procesu opuščanja zemljišč za kmetijsko proizvodnjo postavlja vprašanje, kako opredeliti in kakšno funkcijo nameniti tej zemlji. Za rešitev problema bo potrebno najprej ugotoviti obseg že opuščenih površin in pričakovani nadaljnji trend opuščanja zemljišč ob izpolnjevanju določb kmetijskega reda Evropske unije. S posebno metodologijo bo potrebno še opredeliti, kje in na kakšnih površinah bomo opustili kmetijsko proizvodnjo in način vzdrževanja opuščenih kmetijskih zemljišč. Te naloge naravnost kličejo po projektnih interdisciplinarnih raziskavah, pri katerih bi kazalo upoštevati dosedanje izkušnje in rezultate socialno-geografskih raziskav v Sloveniji in $\mathrm{v}$ zahodnoevropskih državah. V prvi vrsti bo potrebno pripraviti načrte za dodelitev nove funkcije opuščenim kmetijskim zemljiščem in izbrati nosilce ter 
izvajalce programov. Reševanju tega problema bi morali pristopiti takoj, saj vse dosedanje analize dostopnih statističnih kazalcev kažejo na nadaljnje krčenje obsega obdelanih kmetijskih površin. To naj bi bilo še posebej intenzivno v prvih letih po priključitvi Slovenije Evropski uniji, ko naj bi se po nekaterih predvidevanjih obseg obdelanih kmetijskih površin skrčil vsaj za tretjino.

Premalo pozornosti se posveča tudi problemu razdrobljenosti kmetijske zemlje oziroma neustrezni zemljiško-posestni strukturi. To je razvidno tudi iz zapisnika Odbora za kmetijstvo, gozdarstvo in prehrano v Državnem zboru Republike Slovenije z dne 13. februarja 2002, ki je v svojem mnenju k rednemu poročilu Evropske komisije o napredku Republike Slovenije pri vključevanju v Evropsko unijo v letu 2001, v enem od sklepov zapisal:

"Odbor za kmetijstvo, gozdarstvo in prehrano predlaga, da Ministrstvo za kmetijstvo, gozdarstvo in prehrano takoj pripravi in sprejme ustrezne ukrepe ter predpise za povečanje posestne strukture slovenskih kmetij z namenom povečanja konkurenčnosti slovenskega kmetijstva." (Mnenje k rednemu poročilu Evropske komisije ..., 2002).

Kljub številnim problemom, ki jih neustrezna zemljiško-posestna struktura povzroča slovenskem kmetijstvu $\mathrm{v}$ obdobju prilagajanja zahtevam Evropske unije, pa se slovenska politika in odgovorne javne službe le počasi odzivajo nanje, čeprav bi moralo biti reforma zemljiško-posestne strukture opredeljena kot prednostni nacionalni problem Slovenije. Vzpostaviti bo potrebno tudi tesno sodelovanje med načrtovalci prostorskega razvoja in odgovornimi organi državne uprave na eni ter kmeti, njihovimi organizacijami in ostalimi uporabniki prostora na drugi strani. Če bomo hoteli uspešno slediti načelom tržnega gospodarstva Evropske unije, bomo morali tudi v Sloveniji oblikovati ustrezne raziskovalne projekte in se z njimi vključiti v mednarodne raziskovalne tokove. Samo tak pristop nam lahko omogoči Evropi predstaviti specifične probleme slovenskega kmetijskega prostora in te soočiti ob zahtevah slovenskega kmetijstva pri pogajanjih ob vključevanju Slovenije k Evropski uniji. Tega pa ne bo mogoče izpeljati brez interdisciplinarno zasnovanega raziskovalnega dela, ki bo - z uvajanjem novih oblik načrtovanja nadaljnjega razvoja - moralo opredeliti vsebino problemov zelo kompleksne narave. Pri tem bi veljalo slediti delu zahodnoevropskih strokovnjakov, ki kot eksperti sodelujejo pri mnogih programih preoblikovanja evropskega kmetijskega reda in urejanju podeželja.

\section{ZAKLJUČNE MISLI}

Ob vseh naštetih neugodnih kazalcih (neustrezna zemljiško-posestna struktura, neugodna starostna in izobrazbena struktura lastnikov družinskih kmetij itd.), 
ki vplivajo na stihijsko širjenje opuščanja obdelave kmetijske zemlje, se zastavlja vprašanje, v kolikšni meri slovensko kmetijstvo sploh izpolnjuje pogoje za pridobitev sredstev iz evropskih kmetijskih strukturnih skladov. Če za primer pogledamo razpisne pogoje Programa razvoja podeželja 2000-2006 (SAPARD), vidimo, da so do sredstev po tem programu upravičeni le kmetje, ki imajo v uporabi vsaj 8 ha primerljivih kmetijskih površin (od tega vsaj polovico v svoji lasti), so mlajši od štirideset let in imajo ustrezno strokovno izobrazbo. Ker po izkušnjah socialno-geografskih raziskav in rezultatov Kmetijskega popisa 2000 omenjene pogoje izpolnjuje le manjši del kmetov (glede na zahtevano starost manj kot $20 \%$ gospodarjev družinskih kmetij), bodo številne kmetije, s tem pa tudi več kot polovica kmetijskih površin ostala brez ustreznega subvencioniranja, kar pomeni nevarnost nadaljnjega opuščanja obdelave kmetijskih površin.

Ker gre za pereč problem, ki terja ustrezne reforme zemljiške strukture, bi moralo biti proučevanje le-tega opredeljeno kot prednostni nacionalni problem Slovenije, saj vsi kazalci kmetijsko-gospodarske, pokrajinsko-ekološke, regionalno-prostorske in demografske narave, kažejo na nadaljnje stihijsko širjenje neobdelane kmetijske zemlje in preraščanje le-te $\mathrm{z}$ grmovjem ali celo gozdom. Z uvedbo dovoljenih subvencioniranih kvot kmetijske proizvodnje, ki jih narekuje kmetijska politika Evropske unije, se bo ta proces - če ne bomo učinkovito in hitro ukrepali - še pospešil. Na to nam kažejo izkušnje držav Evropske unije, kjer smo ob spoštovanju "evropske" kmetijske politike priča vse večjemu uveljavljanju nove zemljiške kategorije - t.i. socialni prelog (Klemenčič M., 1975). Za razliko od Slovenije pa v državah Evropske unije poteka opuščanje zemlje bolj načrtno. Kmetje oziroma lastniki tako načrtno neobdelane zemlje so za vzdrževanje le-te deležni posebnih plačil iz različnih "evropskih", državnih in lokalnih skladov, ki so namenjena vzdrževanju agrarnih elementov kulturne pokrajine in ekološkega ravnotežja.

Naštete probleme, ki negativno vplivajo na racionalno izrabo kmetijskih površin, bo mogoče razrešili šele na osnovi proučevanj na primerih, specifičnih za kmetijsko-gospodarsko diferenciranost območij Slovenije. Šele znanstveno-raziskovalni napori nam lahko omogočijo takšno oblikovanje kmetijske politike izrabe zemlje, kakršni lahko sledimo v državah Evropske unije in drugih razvitih državah sveta.

Slovenija se je tako ob vključevanju v tržno kmetijsko gospodarstvo in kmetijski red Evropske unije znašla pri vprašanju nadaljnjega razvoja kulturne pokrajine podeželja pred več dilemami:

1. kako se izogniti nenačrtnim stopnjevanim procesom opuščanja obdelave kmetijske zemlje;

2. kako izboljšati neugodno zemljiško-posestno strukturo in lastniško strukturo;

3. kako izboljšati starostno in izobrazbeno strukturo kmečkega prebivalstva; 
4. kako povečati zainteresiranost lastnikov kmetijske zemlje za obdelavo, oziroma kako pospešiti proces najemanja in prodaje zemlje;

5. kako zagotoviti - podobno kot v državah Evropske unije - vzdrževanje za kmetijstvo primernih a neobdelanih kmetijskih površin;

6. po kakšnih kriterijih bomo opredelili mejo med gozdnimi in kmetijskimi površinami, ki bo ustrezala zunanji podobi in funkciji kulturne pokrajine.

Reševanje omenjenih problemov $\mathrm{v}$ okviru državne in kmetijske politike mora biti ena od glavnih nalog države, predvsem zaradi vzdrževanja ekološkega ravnotežja kulturne pokrajine. Vsi omenjeni problemi pa ne smejo biti vzrok za nasprotovanje vključevanja Slovenije v Evropsko unijo, pa naj bo to zaradi njenega geopolitičnega položaja ali zaradi izogibanja reševanja nerešenih specifičnih kmetijskih in gospodarskih problemov, ki smo jih ob priključevanju $\mathrm{v}$ Evropsko unijo v Sloveniji podedovali s kmetijskimi politikami v 19. in 20. st. Pogoj za to pa je novo oblikovanje kmetijske politike in načrtnega razvoja kmetijskega prostora $\mathrm{v}$ okviru človeku prijazne kulturne pokrajine in ob upoštevanju skladnega gospodarskega razvoja, trajnostnega in sonaravnega razvoja, ekološko ravnotežje, zaščite kulturne dediščine itd.

\section{Viri in literatura:}

Cunder, T., 2000, "Changing of Agricultural Structures in Slovenia". Agrarische Rundschau 6, str. 22-25;

Državni zbor Republike Slovenije, 2001: Mnenje k rednemu poročilu Evropske komisije o napredku Republike Slovenije pri vključevanju v Evropsko unijo v letu 2001, Ljubljana, 13. februarja 2002.

Erjavec, E., 1993, Agrarpolitik und bäuerliche Betriebsgrößenstrukturen: Bestimmungsgründe und Möglichkeiten der agrarpolitischen Steuerung des Betriebsgrößenwandels am Beispiel der bäuerlichen Betriebe in der Landwirtschaft Sloweniens : Inaugural - Dissertation, Wien, 1993, 190 str.

Hilpert, M., 2002, Angewandte Sozialgeographie und Methode. Überlegungen zu Management und Umsetzung sozialräumlicher Gestaltungsprozesse (Angewandte Sozialgeographie Nr. 47), Augsburg: Universität Augsburg, Lehrstuhl für Sozial- und Wirtschaftsgeographie, 2002, 222 str.

Klemenčič Marjan, 1975, Sodobni prelog kot indikator transformacije pokrajine v Sloveniji - magistrska naloga, Ljubljana, Filozofske fakultete, Oddelek za geografijo, 117 strani.

Kovačič, M., 1999, Razvojne tendence v kmetijstvu Slovenije in vpliv na kulturno krajino. Kulturna krajina $\mathrm{v}$ dinamiki razvoja in varstva - Zbornik 6. letnega srečanja Društva krajinskih arhitektov Slovenije (Aleš Mlakar, 
Polona Marinček, Darja Matjašec, ur.), Ljubljana, Društvo krajinskih arhitektov Slovenije, str. 53-59.

Kürbus, T., 1992: Drobno gospodarstvo kot element socialnogeografske transformacije slovenskega podeželja - doktorska disertacija. Ljubljana, Filozofska fakulteta, Oddelek za geografijo, 403 strani.

Pelc, S., (ur.), 1999: Navodila za izvedbo programa uvajanja CRPOV in izdelavo razvojnega projekta CRPOV, Ljubljana, Ministrstvo za kmetijstvo, gozdarstvo in prehrano, Sektor za podeželje, 112 strani.

Plut, D., 2001: Okoljevarstveni vidiki prostorskega razvoja Slovenije, Ljubljana, Znanstveni inštitut Filozofske fakultete, 292 strani.

Popis kmetijskih gospodarstev, Slovenija 2000 (Rezultati raziskovanj, št. 777), Ljubljana, Statistični urad Republike Slovenija, 2002, 256 strani.

Pregled kmetijske politike: Slovenija, Ljubljana, Ministrstvo za kmetijstvo, gozdarstvo in prehrano republike Slovenije, 2001, 184 strani.

Schaffer, F. (ur.), 2002: Evalution der Geographie in Bayern: Umsetzung der Impulse in Augsburg, Augsburg, Universität Augsburg, Lehrstuhl für Sozial- und Wirtschaftsgeographie, 74 strani.

Študije o kmetijski izrabi tal v treh vaseh Jugoslavije. Grografski vestnik 34 (1962), str. 26-81.

\title{
DEVELOPMENT AND NEW THEORETICAL AND METHODOLOGICAL CONCEPTS AND APPLICATIONS OF SOCIAL GEOGRAPHY
}

\author{
The Case of Rapid Reduction of Agricultural Land in Slovenia, \\ Leading to Less Use of Farm Land, Endangerment of the Cultural \\ Landscape and Destruction of the Ecological Equilibrium
}

\section{Summary}

It is characteristic of the development of social - and its connected political geography that along with new dynamic concepts, new theory, methodology and applications are discovered. They are especially relevant to new developments in the landscape of the modern democratic society from local, national, European and global perspectives. This concept enables the social geographer to define problems of contemporary processes in the landscape while taking into account all the factors that determine decisively the development and redevelopment of the image and use of the landscape. This concept within interdisciplinary research and with adequate access to the planning of regional 
development contributes towards purposeful development of the cultural landscape - under the condition that planning is in accordance with the needs of all factors that use the landscape (farming, industry, handicrafts, tourism, traffic, the public sector, etc.). To achieve this, planners and users of the land-scape must be closely interconnected and involved with the planning of regional development, as well as in the execution of any plan of development of the cultural landscape.

With this concept of social geography we witness a new philosophy in the transfer of methodology and theory in praxis on the basis of adequate concepts of management. With such methodology, social geography has succeeded in establishing its place in new, modern and interdisciplinary research and the planning of landscape at all stages from local to global. Because its contributions are based on the starting-points of interactions, integrating social and economic development with protection of the environment, they are already to be found in concepts and recommendations of the European Union for development of rural areas.

In contemporary spatial processes, in the formation of European integration and globalization, farming represents one of the most important factors in the planning of the agrarian landscape and also the cultural landscape. How important farming is, we can see in the example of Slovenia, where one-third of the country's area is used for farming (which also contributed to its formation). We should not forget that Slovene farming, as part of the world market, will be soon, to a large extent, dependent on the farming policies of the European Union, i.e., the policies of additional payments and quotas for subventions. Also the land designated for farming will be soon indirectly dependent on EU policy; after Slovenia enters the EU it will have to follow the EU's rules. We have to mention in this context that due to European farm policy the extent of cultivated land has been reduced during the last decades. We can foresee that due to further technological development, the space for cultivated farm lands will be further reduced to the regions most suitable for farming.

Because of the development of modern technology in farming, the phenomenon of surpluses of arable land is a problem in all developed countries of the world. The ways of handling the surpluses of arable land differ from country to country. In some countries arable non-farm lands might be abandoned to the encroaching forests. Elsewhere those lands are treated with additional financial help, to enable them to be farmed again. Farmers and/or owners of such land are given special payments from different European, state and local funds for farming and ecology. Among the states that are leaving arable lands on which there is no farming to the woods is Slovenia, which does not pay enough attention to its farm policy nor to the planning of regional spatial development. 
With modern views on protecting the cultural landscape also from an ecological point of view, Slovenia faces the question of what to do with this land. First, the volume of already unused arable land and the expected further loss of arable lands to the woods if the trend continues after Slovenia's entrance into the EU will have to be assessed to solve the problem. Special methodology will be needed to decide where and to what extent we are going to abandon arable lands. In spite of the seriousness of the problem, neither Slovene farm policy makers nor scholars nor public service providers who deal with regional planning are paying enough attention to it.

We geographers are pointing out the problems that resulted from urbanization of the farm landscape on the one hand and not enough development of some regions on the other hand from the 1970s onward. Especially, we should emphasize that, during the course of the last thirty years, Slovene geographers have been included in international projects dealing with problems of land use in Slovenia. With our publications on the subjects published at home and abroad, we are internationally recognized and comparable to other experts in the field. It is strange, therefore, that the results of our research, which was quite expensive, are not used enough, because of the lack of interdisciplinary thinking on the part of those who are today in charge of farming and regional development. The results of the research, theory, methodology and application of social geographic research are not used enough even today, in spite of the fact that, during the start of urbanization of the rural landscape in the 1970s, social geographers pioneered in pointing out the differences in the intensity and ways the rural landscape was being used and the cultural landscape was disintegrating. Because the above-mentioned results of social geographic research were not taken into account enough, the problem of abandoned farmland, especially on the less-developed periphery, did not get the attention it deserved.

Today, also, we only have data on growing of the forests on arable land and on the area of arable lands that are not worked as a result of "rotation of crops." We do not have data, however, on the growing amount of abandoned farmland suitable for farming. This is happening sporadically on certain small parcels of land, but it is happening also on smaller as well as larger complexes of arable land.

There are different reasons for non-use of arable farmlands in Slovenia. One of the main reasons is unsuitable division of land. An average farm in Slovenia had approximately $5.9 h a$ (16.6 acres) of land. Out of that, $3.2 \mathrm{ha}$ (7.9 acres) were farmlands and $2.5 \mathrm{ha}$ (6.2 acres) arable land not being used. This very unsuitable land structure of very small farms changed for the better in the last decade, mainly on account of buying of additional land and renting of land. Today most of the farms have 5 to $10 h a$ (12.4 to 24.75 acres) of land. Also increasing is the number of farms that are working on more than $10 \mathrm{ha}$ 
(24.75 acres) of land. The percentage of farms that are making enough money for the family to survive is, if we compare these data to the situation in the EU, very low.

Also traditional and old fashioned land division influences the growing percentage of lands not being worked. According to the Farm Census Data of 1990, there were 5.5 million Slovenian private sector lots that were ca. $30 \mathrm{ha}$ ( 0.74 acres) in area. Those lots were united into 955,000 divided parcels of land that were sometimes more than 6 miles away from the farm. This is making agricultural production more expensive (because of loss of time and higher expenses of transport) and is not allowing for rational use of the newest farm technology.

Deserting working on arable farmland is a phenomenon that can be followed in Slovenia from its beginnings in the 1960s onward, when farm owners started to seek employment outside the farms. From then on, we can also follow creation of mixed worker-farmer households. At first the process of land desertion was a phenomenon characteristic of areas less suitable for farming. But we can follow desertion of lands suitable for farming as well, especially after Slovenia became an independent state. The reasons for that may be found in 1) the unsuitable age structure of members of the households on family farms, 2) the fact that farms were too small for a market economy, and 3) the low level of education of Slovene farmers. When we take into account all the above-mentioned factors, we have to ask ourselves to what extent Slovene agriculture meets the requirements to get funding from European Agricultural Structural Funds. According to the rules of the Special Accession Program for Agriculture and Rural Development, 2000-2006 (SAPARD), only farmers who are using at least $8 h a$ (19.8 acres) and at least one-half of their property, who are younger then 40 years old and have proper education qualify. Social-geographical research and the Farm Census Data of 1990 show that only a small number of the farmers are eligible for help from those funds, since, for example, less than $20 \%$ of the heads of the farms are younger than 40. So numerous farms will not get any subventions. As a consequence, the process of desertion of farming will continue.

The consequences of desertion of work on the farmlands are most visible on the plains and in some smaller basins and valleys, as well as on numerous peaks of tertiary hills of Sub-Mediterranean (Šavrini, Brkini), Sub-Pannonian (Goričko, Slovenske gorice, Haloze) and Sub-Alpine regions. Those are the regions that could become suitable for further production only if smaller lots were united into larger complexes and the farms were enlarged. In some Karstic regions and valleys, especially at places that are far from other villages or farms, we can follow complete desertion of work on the farms. Deserted are 
also once-upon-a-time well- used grasslands in the midst of the forests in the mountainous regions.

As we have already mentioned, we in Slovenia are not taking enough into consideration the phenomenon of farmland desertions. This problem should be characterized as a priority national problem. Since all the factors of our agricultural-economic, regional-ecological, regional-spatial and demographic future point to further widening of the un-worked arable land (which will lead to bush or even wood growth), once Slovenia becomes part of the EU and Slovenian agriculture becomes part of the system of subvention quotas, this process - if we are do not intervene properly - will go even further. The experiences of other states of the European Union show that volume of unused arable lands, which are suitable for farming is widening. In the states of the $\mathrm{EU}$, this process is much more planned than in Slovenia. Farmers or owners of the lands on which they are not working are given special payments from different European, state and local funds with the aim of keeping agrarian elements of the cultural landscape and the ecological balance intact.

The above-mentioned problems, which are influencing negatively the rational use of farmlands, will be solved on the basis of research of cases specifically for agriculture, economic differentiation of the regions of Slovenia. Based on the results of this research, we will be able to create such use of agricultural lands as to make Slovenia comparable to the current states of the EU and the other developed countries of the world.

Slovenia's dilemmas at its accession to the EU are the following, as far as the topics of this paper are concerned:

1. how to avoid unplanned accelerated processes of deserting farmland use;

2. how to improve the inadequate structure of farms as well as ownership of the farms;

3. how to improve the age structure and educational structure of the population on the farms;

4. how to make farming more interesting and how to accelerate the process of renting and selling of the land; and

5. how to assure, like the current countries of the EU do, the maintenance of those lands that are suitable for farming but are not currently being farmed.

Finding solutions to these problems in the context of state agricultural policy must be one of the main tasks of the state, especially in order to keep the ecological equilibrium of the cultural landscape.

All the above mentioned problems however should not be the reason to oppose accession of Slovenia to the EU. We must, however, define our agricultural policy taking into account development of the agricultural landscape within the cultural landscape and also in the context of ecological development. 